\title{
Person-first language: Laudable cause, horrible prose
}

$\mathrm{T}$ here's a reason Ernest Hemingway didn't call his novel The Person Who Was Male and Advanced in Years and the Sea. $\mathrm{He}$ valued economy of language over verbosity, so "Old Man" worked fine to describe his titular character. One can only imagine what Papa Hemingway would think of person-first language.

Of course, the purpose of personfirst language - such as "person with a disability" instead of "disabled person" — isn't to produce writing that is more concise, clear or lyrical. It's supposed to promote the idea that personhood is not defined by disability or disease.

"It's a fine idea. But, with language, we cannot get away from the fact that there is a problem," says Helena Halmari, professor of linguistics and chair of the English department at Sam Houston State University in Huntsville, Texas. "We cannot make these things be different by rules of language."

To use an academic phrase, one must consider the "direction of causation." Can manipulating language cause positive changes in society? Or are positive changes in society subsequently reflected by new terminology? "I think it is a loop, but more so a change in society can lead to a change in language," says Halmari.

Furthermore, trying to outrun stigma through linguistic gymnastics often produces short-lived results. Consider what linguists call the "euphemism treadmill." Over time, lexical euphemisms have a tendency to take on the stigma of the words they replace, so new euphemisms are coined to take their place (www.cmaj.ca/lookup /doi/10.1503/cmaj.109-3308).

Thus "lame" becomes "crippled," which becomes "handicapped," which becomes "disabled," which becomes "differently abled," and so on. Personfirst language is a structural euphemism. It is possible, then, that "person with autism" will one day be deemed offensive - as some now consider "autistic

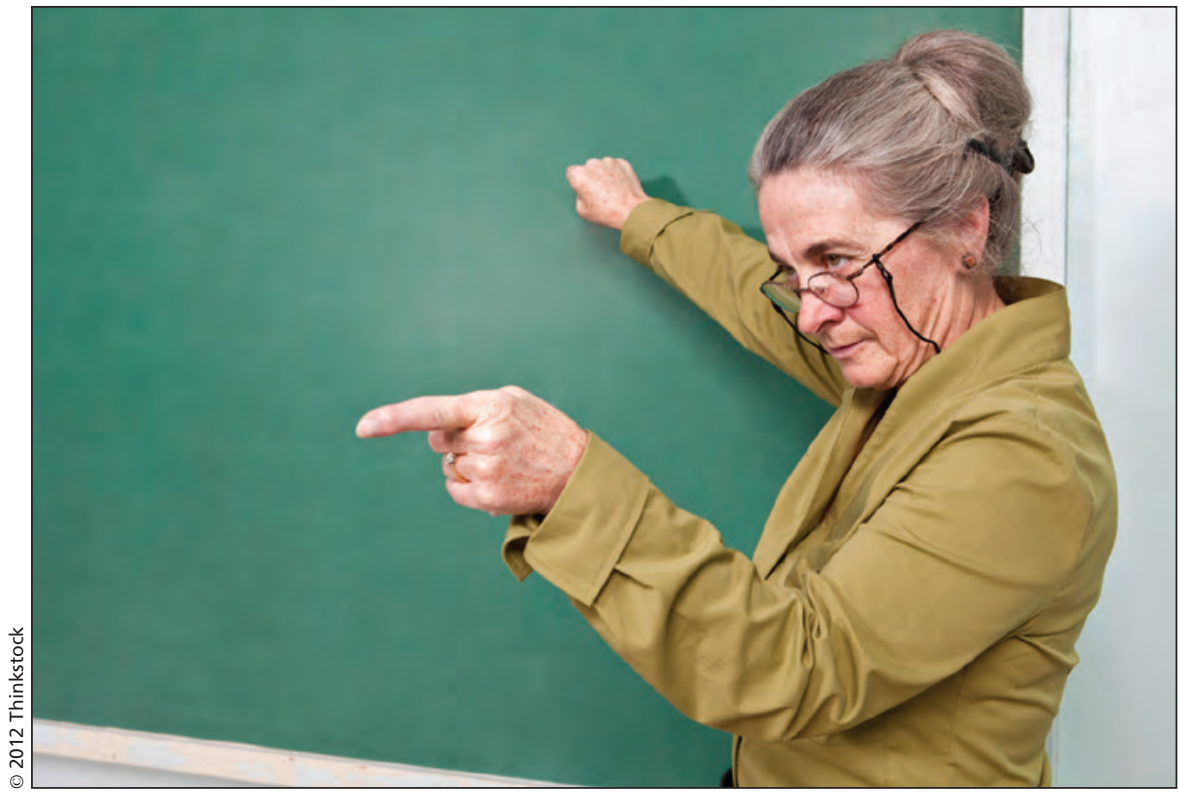

Person-first language breaks a basic law of strong writing: Say as much as possible in as few words as possible.

person" - and demands will arise for a new grammatical twist.

"Whatever is negative or taboo, such as disease or illness, we try to avoid talking about it," says Halmari. "It's a fallen world, and we need to talk about unpleasant and sad things."

The structure of person-first language also does a poor job of deemphasizing disability, notes Halmari. In English, emphasis naturally occurs at the end of sentences. This is why, when asked if there are rules for humour writing, Washington Post columnist Gene Weingarten replied: "Only one. I always try to put the funniest word at the end of the sentence underpants."

So by pushing mention of a disability or disease deeper into a sentence, adherents to person-first language may actually be adding stress to those words. "What you have at the end of a sentence is the new information that gets the most attention," says Halmari. "If it's earlier, it doesn't get quite as much attention."

Others have noted that tucking the disability behind the noun may contribute to stigma rather than reduce it.
After all, most adjectives with positive connotations precede nouns. We do not typically say a "person who is beautiful," for instance, or a "person who is intelligent." Sticking a word in the shadow of a noun can create the impression that there is something inherently wrong with it that it should be hidden.

"The people who started it, like so many movements, were well-intentioned and thoughtful, but much of what they created was just bafflegab," says Kenneth Louis, a fluency disorders expert who teaches speech-language pathology at West Virginia University in Morgantown. "All I can see is that it makes terms that were perfectly acceptable unacceptable."

Person-first language also breaks a basic law of strong writing: Say as much as possible in as few words as possible. Though fiction writers are sometimes granted leeway - allowed to purple their prose for poetic purposes - concision is extolled by all teachers of nonfiction writing.

"Clutter is the disease of American writing," William Zinsser wrote in $O n$ Writing Well. "We are a society stran- 
gling in unnecessary words, circular constructions, pompous frills and meaningless jargon."

In The Elements of Style, considered by many to be the Bible of English grammar, William Strunk, Jr. and E.B. White practise the brevity they preach: "Omit needless words. Vigorous writing is concise."

This is the reason members of some disability groups denounce person-first language, suggesting that clarity and quality should not be sacrificed at the altar of sensitivity. In the Braille Monitor, the main publication of the National Federation for the Blind in the United States, pressure to use "people who are blind" instead of "blind people" has been rebuffed as being "awkward, tiresome, and repetitive, and it makes articles needlessly long" (https://nfb .org/images/nfb/publications/bm/bm09 /bm0903/bm090309.htm).

"It is unwieldy and repetitive, and any ear tuned to appreciate vigorous, precise prose must be offended by its impact on a good sentence," the editorial states. "But proponents of this formulaic circumlocution have decided that mention of the person must always precede reference to his or her disability or the effect will be to show disrespect for the individual under discussion. The result has been to shame many good speakers and writers into forms of expression to which they would never otherwise have stooped."

— Roger Collier, CMAJ

CMAJ 2012. DOI:10.1503/cmaj.109-4338

Editor's note: Third of a multi-part series.

Part I: Person-first language: Noble intent but to what effect? (www.cmaj.ca/lookup/doi/10.1503 /cmaj.109-4319).

Part II: Person-first language: What it means to be a "person" (www.cmaj.ca/lookup/doi/10.1503 /cmaj.109-4322). 